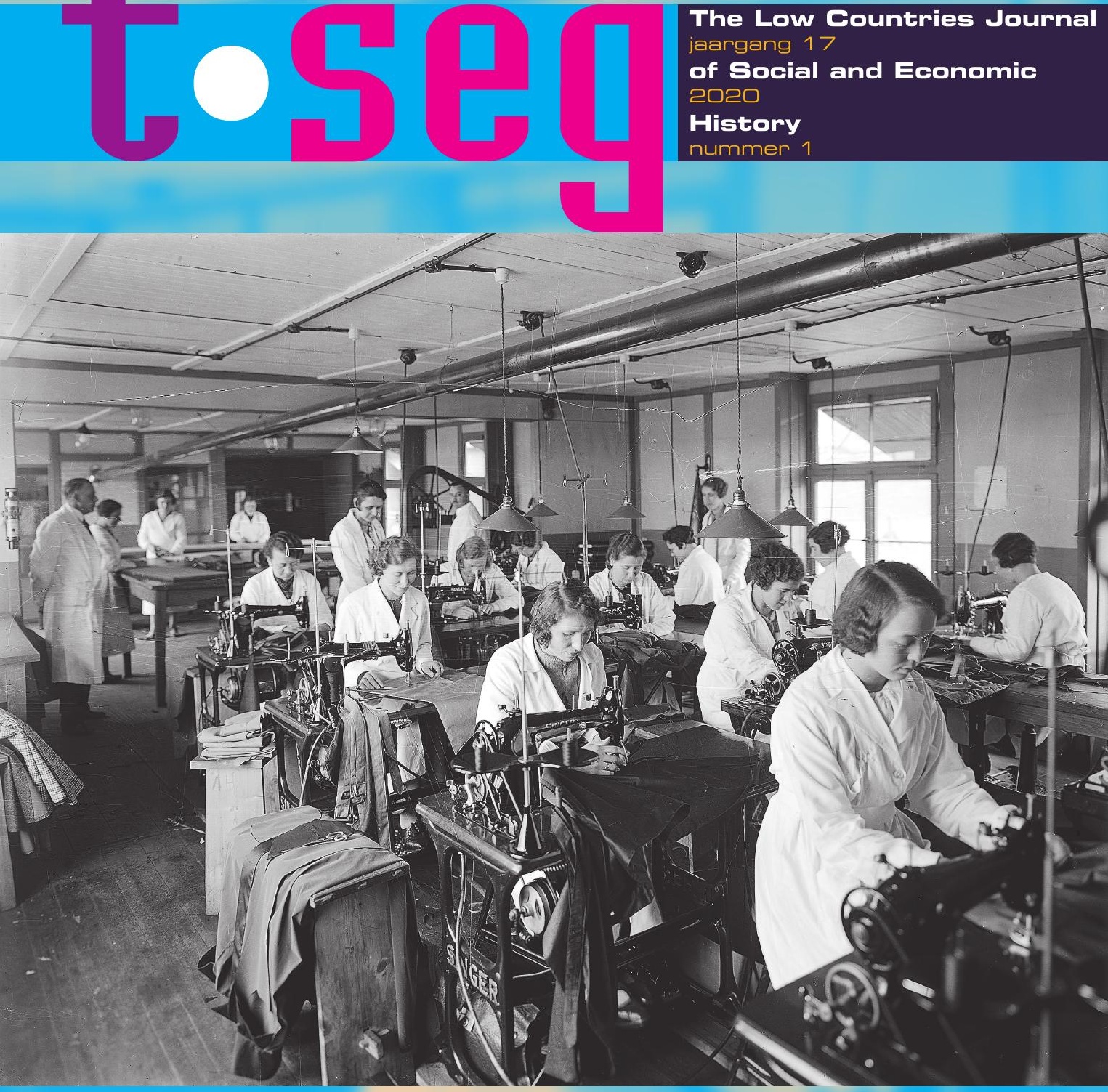

Special Issue: 'Het androcentrisme voorbij?' 25 jaar gender en sociale geschiedenis

- Arbeid van vrouwen in Limburg [Knotter]

- Androcentrisme in de historische demografie [Janssens]

- Van regionaal naar globaal [Van Nederveen Meerkerk]

- Feminationalisme [Schrover] 


\title{
The Indian Ocean and its Implications for a Global Intellectual History of Political Economy
}

\author{
Mattia Steardo \\ TSEG $17(1): 145^{-1} 5^{6}$ \\ DOI: $10.1835^{2} /$ tseg.1129
}

Books under review:

Johan Mathew, Margins of the Market. Trafficking and Capitalism across the Arabian Sea (Oakland 2016)

Fahad A. Bishara, A Sea of Debt. Law and Economic Life in the Western Indian Ocean, 1780-1950 (Cambridge 2017)

Tariq O. Ali, A Local History of Global Capital. Jute and Peasant Life in the Bengal Delta (Princeton 2018)

\section{Introduction}

Exploring differences and similarities across wide spatio-temporal scales, global history is fostering 'a much stronger sense of commonalities in human affairs, ${ }^{1}$ without falling into the Eurocentric perils of an Enlightenment-style kind of universalism. One of the biggest challenges for global historians is therefore the attempt to develop non-universalizing global frameworks to study in a comparative way large-scale local processes. As the field of global history expands and reaches out to new academic domains - from economic to social, cultural and intellectual history - these challenges remain. It is in this context that we encounter an increasing interest from the fields of global economic and the more recently developing global intellectual history in the ways in which European concepts determined and influenced ideas and prac-

1 D. Washbrook, 'Problems in global history', in: M. Berg (ed.) Writing the history of the global. Challenges for the 21 st century (Oxford 2013) 21-31, 22. 
tices of political economy outside the West, especially in the era of imperialism. This review article discusses three recent publications that take up these questions in their study of the history of political economy in the Indian Ocean, and explores their possible implications for the study of global and intellectual history in the context of the wider resurgence of the interest in new histories of capitalism and a materialist turn in these fields.

\section{The Indian Ocean World. Laws, merchants and peasants}

During the age of global empires, the Indian Ocean was a space of encounter in which the 'dominance without hegemony' of the British Empire had to deal with pre-existing commercial and political networks. Europeans and local actors were constantly confronting or cooperating in order to exploit the growing commercial opportunities provided by the expansion of the global market and of the global demand of commodities. The books under review explore this interregional arena during a long nineteenth century marked by a progressive transition to a modern capitalist economy. Their focus is on the different degrees of penetration of the universalizing British political economy, backed by coercion through law, and the local creative responses to this process, resulted in contestation of or accommodation to the new practices.

The first two books describe the Western Indian Ocean, the political economy of which was built around the revenues from trade in luxury goods - ivory, cloves, dates. Their combined reading allows us to grasp the image of a flourishing commercial world, which drastically changed after its incorporation into the capitalist global market, and to understand the long process of contestation of its rule by local actors. The third publication deals with the Bay of Bengal, where the British Empire, thanks to its political leverage, replaced a market-based system in the textile industry 'by one embedded in coercion of the intermediary merchants and the manufacturing artisans' since $1765 .{ }^{2}$ Gradually, the production of luxury textiles was replaced by bulk commodities, such as rice and jute. Bengali peasants had little room for contestation at the end of the nineteenth century, thus accommodating in a creative way their everyday practices to their new market-entangled lives. The combination of the three publications gives us a hint of the process of the

2 O. Prakash, 'From negotiation to coercion. Textile manufacturing in India in the eighteenth century', Modern Asian Studies 41:6 (2007) 1331-1368, 1334. 
transition to capitalism in the region, describing how local actors were reacting to and participating in this social change.

Fahad Bishara narrates his story in A Sea of Debt. Law and Economic Life in the Western Indian Ocean, 1780-1950 following the waraqas, the main commercial contracts used in the Arabian Sea. The author first reconstructs the growing commercial society of the Western Indian Ocean in the late eighteenth century, in which the increasing opportunities brought by the expansion of the world market were being exploited by rulers and merchants seeking for profits or power. The law was the main instrument that facilitated the expansion of trade, binding actors far away from each other in chains of obligation and credit. The second part of the book describes change in the multifaceted world of the Arabian Sea and in its political economy followed by the arrival of the British Empire. Here, the increasing political influence of the British was preceded by a legal penetration: effectiveness in enforcing contracts determined the preference of the most powerful local actors for British law to resolve lawsuits. Eventually, legal prominence resulted in political hegemony, and in the disappearance of Arab legal and commercial instruments after the Great Depression of the 1930's. Bishara managed to write a non-imperial history of 'an oceanic space bound together as much by law as by nature, empire, or trade networks, ${ }^{3}$ in which local economic practices are brought back to life, as well as their progressive change and disappearance in the course of the contact with British political economy and in particular its legal apparatus.

Johan Mathew's choice in Margins of the Market. Trafficking and Capitalism across the Arabian Sea is to describe the changing commercial environment of the Indian Ocean that a nākhudās (captain) could see from the deck of his dhow, the iconic regional vessel. In this way, he is able to soften traditional geographical boundaries, following the sea routes of merchants and traffickers who were dealing with the already established military and legal hegemony of the British Navy, between roughly the 186 os and the 1950s. The main argument of the book strongly determines its structure: Mathew's claim is that 'the contestation over the boundaries of the market is constitutive of capitalism itself' and each chapter of the book is devoted to a domain of contestation between British officials and merchants. ${ }^{4}$ Thus, through the description of the changes in the economic and legal environment

3 F.A. Bishara, A sea of debt. Law and economic life in the Western Indian Ocean, 1780-1950 (Cambridge 2017) 11.

4 J.Mathew,Margins of the market. Trafficking and capitalismacross the Arabian Sea(Oakland 2016) 2. 
brought by the new infrastructures of trade based on steamship lines, the book depicts the process of framing out of the capitalist market three of its constitutive commodities: land, labour and capital, in the form of firearms, slaves and money. ${ }^{5}$ However, the creation of the capitalist market was not unidirectional, because local actors participated in its legal construction through contestation in commercial courts and illegal practices in trade. The book describes 'how capitalism in the Arabian Sea was framed both by colonial states that formatted trade according to capitalist categories and by trafficking networks that arbitraged across the margins of these markets'. ${ }^{6}$

The last book under review is A Local History of Global Capital. Jute and Peasant Life in the Bengal Delta by Tariq O. Ali. It is centered on a single commodity - jute - but it is also centered on the people who produced it, the Muslim peasants of the Bengal Delta. The book starts with the description of the reconfiguration of the Bengal countryside brought on by the high demand for jute on the global market. In this way, following the fluctuations of jute prices in the world market, the author describes the changing economic, social and political practices of Muslim peasant households. The narrative is divided in two: in the first part, the prosperity brought by jute is the driving force behind the fashioning of new consumption patterns, as well as geographical configurations in the region; in the second one, World War I determined the collapse of jute prices and the subsequent immiseration of the peasantry. Ali shows how jute informed also the religious and political discourse in the period under study, as well as the dramatic consequences of the process of immiseration brought by a progressive over-reliance on jute cultivation instead of rice, resulting in the catastrophic Bengal famine of 1943. Ali wrote a convincing local history of global capital because he describes masterfully in a non-teleological and non-universalizing way the changes in local communities brought on by a global phenomenon, the incorporation into the capitalist global market. In fact, 'local histories were shaped as much by the particularities and specificities of peasant communities as they were by global capital's attempt to conjure an abstract universality' ${ }^{7}$

5 The author argues that the expulsion of these three commodities 'was the foundational work of free market capitalism' in the Arabian Sea. He defines the concept of framing out as 'a concerted effort on the part of bureaucracies to push certain practices outside the calculations of markets'. See: Mathews, Margins, 8.

6 Mathew, Margins, 20.

7 T.O. Ali, A local history of global capital. Jute and peasant life in the Bengal Delta (Princeton 2018) 5 . 


\section{Agency, law and capitalism}

In their description of economic transformation in relation to imperialism, three key themes stand out: the agency of historical actors, the role of law in economic life, and their conceptualization of capitalism. The attention for individual agency is a common feature of the three books: in order to avoid grand narratives or universalizing reconstructions, the authors stick closely to primary sources, bringing out individual stories that enrich and substantiate the narrative, as well as uncovering a universe of different forms of everyday economic life. ${ }^{8}$ This is possible mainly through a reading against the grain of reports in the colonial archives, combined with local sources that range from political pamphlets and literary works in the case of Ali, to a great array of Arabic legal contracts and court cases for Bishara's book. Mathew, instead, has to deal with the most difficult hermeneutics of the sources: the study of smuggling is 'afflicted with the problem of the absent and unknown'9 because of the very nature of illicit activities. The reliance on primary sources results in the appreciation of the different degrees of agency that local actors experienced because of the progressive legal creation of a capitalist market in the Indian Ocean World. For instance, merchants in the Western Indian Ocean hasted to register their waraqas at the British Consulate when the Sultan of Oman made clear that this was needed to base any legal claims on them. In doing this, local merchants shaped British understanding of the content of each wara$q a$ according to their self-interest, thanks to the inherent complexity of translating politico-economic concepts from one legal system to a radical different one. ${ }^{10}$

The legal system determined the room for agency of the economic actors. In fact, the institutionalization of liberal market governance was implemented through the standardization of commercial laws and practices, which in the name of economic rationalization created a favorable commercial playing field for Europeans. ${ }^{11}$ While the governmental power of the British Empire was far from absolute, even in colonial India, it is interesting to note how the entanglement in the cap-

8 W. Sewell, 'A strange career. The historical study of economic life', History and Theory 49:4 (2010) 146-166.

9 Mathew, Margins, 15.

10 Bishara, Sea of debt, 125-149.

11 For a thorough discussion of the relationship between market governance and law, see: R. Birla, Stages of capital. Law, culture, and market governance in late colonial India. (Durham/London 20o9) 1-30. 
italist market eroded the agency of economic actors in the Indian Ocean world, especially as a consequences of credit relations. The penetration of British concepts of political economy and their progressive predominance, backed by the legal and military apparatus of the Empire, determined an increasing asymmetry of power among the economic actors, depending on their familiarity with the colonial state. Thus, Indian merchants worried about their credit in the Omani Sultanate lobbied the colonial power in order to back up their offensive against Arab commercial practices - such as the waraqa and the khiya $r$ - that limited the possibilities of dispossession (the only option to recall a debt in the absence of liquidity during periods of economic depression). Regarding maritime trade, British officials obliged every ship to pay a bond equivalent to the value of the entire cargo. Authorities would return the bond only in case of the sale of the entire cargo, but this system favored certain ports over others, and thus British sponsored steamship lines over local dhows. ${ }^{12}$ Credit played the role of instrument of access to the opportunities in a growing commercial environment, as well as the obligation that facilitated dispossession by more powerful economic actors during periods of crisis. Interesting to note, dispossession after the financial collapse determined by the Great Depression in 1929 was the coup de grace to the indigenous economic world of the Western Indian Ocean. Until this point, Europeans were not fully able to gain control of entire commodity chains, as had happened at least one century earlier in colonial Bengal.

Law represented the dispositive of governance used to create the structure of the capitalist market, but the price to pay for writing histories of 'capitalism in action' is the risk not to provide an exhaustive discussion of much debated concepts with which these books deal, i.e. capitalism. For instance, Bishara talks from time to time of the 'emerging forces of modern capitalism', but never defines what he means by it. On the other hand, both Mathew and Ali rely on Dipesh Chakrabarty's distinction between History 1 and History $2 .{ }^{13}$ The first history is composed by the social domains that work according to a profit-maximizing capitalist logic in a given society. Instead, History 2 represents social relations that do not readily conform to such a logic. The story of the transition to capitalism is the story of the penetration and of the progressive but never accomplished dominance of the elements of History 1 in a

12 Mathew, Margins, 41.

13 D. Chakrabarty, Provincializing Europe. Postcolonial thought and historical difference (Princeton 2000) 62-71. 


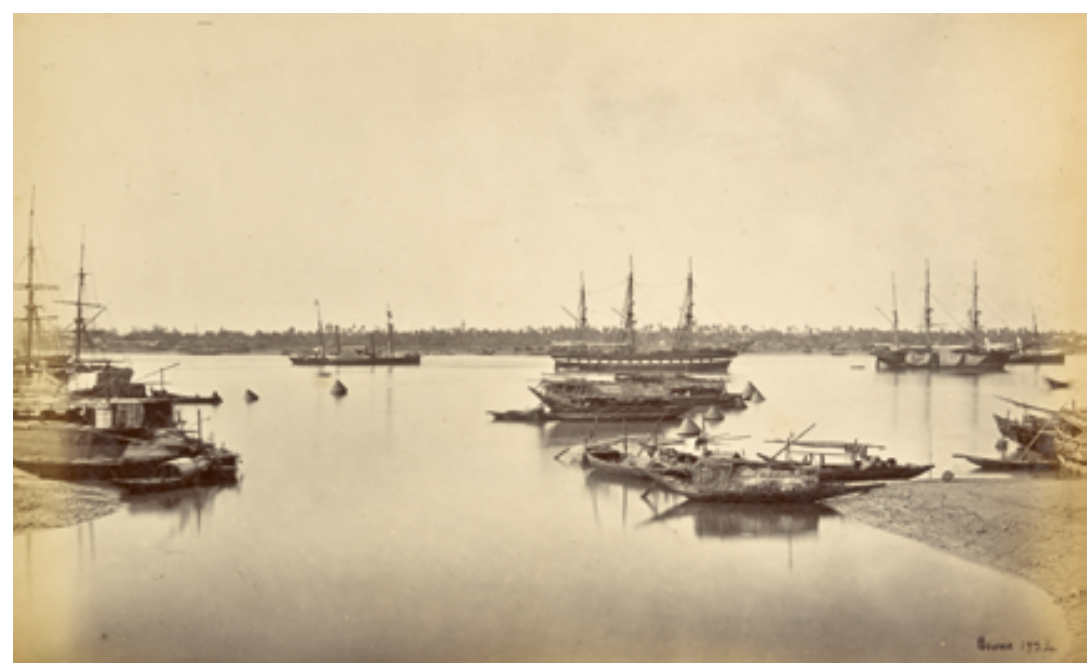

Illustration 1 Calcutta: View of shipping from Hastings Bridge, showing the steamer 'Mauritius' and other vessels, photo by Samuel Bourne (source: JP Getty Museum Los Angeles, coll. no. 84.X0.1126.97).

given society, and their continuous attempt to subsume the non-capitalist nature of History 2 . Thus, the British effort to standardize the value of currencies in the Indian Ocean (History 1) encountered the reluctance of the local population, accustomed to non-decimal systems of mental arithmetic (History 2). ${ }^{14}$ Alternatively, the monetary revenues from the sale of jute for the global market (History 1) triggered an increase in the demand for traditional vests, instead of cheap English clothes (History 2). ${ }^{15}$ Again, this is an effective way to describe 'capitalism in action', but it remains somewhat unclear what the central elements of this History 1 are.

\section{From the Indian Ocean to a global (intellectual) history of political economy?}

The studies under review here offer promising examples of how studies of developments in specific regions and timeframes can contribute to the call to expand global frameworks with new domains and new cases. ${ }^{16}$ And although this global historical agenda has since the beginning

14 Mathew, Margins, 117-124.

15 Ali, A local history, 47-49.

16 See for instance: J. Lucassen, 'Deep monetization in Eurasia in the long run', in: R.J. van der Spek 
been dominated by an economic historical approach, these studies under review are not (global) economic histories in the classic sense, and their contributions invite us to reflect on an interesting historiographic momentum in the development of global, economic and intellectual history.

One of the most recent issues of the Journal of Global History opened with an editorial note explaining why more than half of the articles were devoted to global economic history. While editors often publish special issues about a particular topic, this time the choice was 'serendipitous': the appearance of a non-deliberate special issue revolving around 'how states affect economic outcomes' was indicative of the success that the global turn has had on economic history, and of the contemporary renewed interest in economic history in general. ${ }^{17}$ Ever since Pomeranz's seminal work, economic historians rapidly developed increasing global historical methods to debate about the periodization, the causal factors and the processes that determined the Great Divergence in economic outputs and standards of living between (different parts of) the 'West' and (different parts of) the 'Rest'. ${ }^{18}$ After almost twenty years of debate, however, the continued interest seems to reflect a growing consensus on, and discomfort with, the imprecision of the mainstream neoliberal discourse of a market-driven economic growth and a Eurocentric interpretation of history in fixed stages of economic development. At the same time, it seems the last strands of the 'cliometric revolution' are consuming their intellectual strength, calling for approaches that are less centered on economic growth, the capture of historical processes with solely measurable developments, and the refinement of statistical methods. ${ }^{19}$ Risking to sacrifice the historical sensation and nuance

and B. van Leeuwen, Money, currency and crisis. In search of trust, 2000 BC to AD 2000. (Oxon/New York 2018); J. Lucassen and L. Lucassen, 'Theorizing cross-cultural migrations. The case of Eurasia since 1500', Social Science History 41:3 (2017) 445-475; M.B. Jerónimo, 'Imperial globalizations' in: C. Antunes and K. Fatah-Black (eds.), Explorations in history and globalization (London 2016); E. Vanhaute and H. Cottyn, 'Into their land and labours. A comparative and global analysis of trajectories of peasant transformation', icas Review Paper Series 8 (2017).

17 W.G. Clarence-Smith, 'Editor's note - Economic history cluster', Journal of Global History 13:3 (2018) 307-308.

18 K. Pomeranz, The Great Divergence. China, Europe, and the making of the modern world economy (Princeton 2000). For an exhaustive overview of the debates in economic history before and after Pomeranz's book see: P. Vries, 'Are coal and colonies really crucial? Kenneth Pomeranz and the Great Divergence', Journal of World History 12:2 (2001) 407-446; P. Vries, 'The California school and beyond. How to study the Great Divergence?' History Compass 8:7 (2010) 730-751.

19 For an overview of the historiography in economic history see: J.W. Drukker, The revolution that bit its own tail. How economic history changed our ideas on economic growth (Amsterdam 2003). For a more 
on the altar of increasingly complex quantitative methodologies, the research agenda of the new institutionalists inspired by Douglass C. North seems not to have been sufficient to take away economic historians' growing dissatisfaction.

The rediscovery of the study of capitalism, and the wave of 'new histories of capitalism' in US and increasingly also in European universities after the Great Recession, might be one of the most striking recent examples of this. In fact, the current concerns about growing inequalities inherent in the capitalist economic system have been faced by historians with attention for the mechanisms that have brought the system itself into being. Although this new wave of capitalism studies has been critiqued for lacking strong theories and definitions of the phenomenon of capitalism itself, which could represent a serious backlash for this academic enterprise,${ }^{20}$ the aversion to theory seems to be slowly fading away, as a recent work about the capitalization of the US economy shows. ${ }^{21}$ This renewed interest in the history of political economy in the wave of new histories of capitalism is accompanied by developments in intellectual and imperial history. International and comparative contributions to intellectual history shed new light on the history of the conceptualization of political economy, (early) capitalist order, and its connection to early European imperial expansion. ${ }^{22}$

The three studies reviewed here, however, remind us that these historiographic developments should not introduce yet another phase of studying (European) ideas and their circulation around the globe. In fact, historians should pay attention to how local practices of political economy persisted, changed or were displaced in imperial and non-European contexts around the globe. It is in this context that it is interesting to consider the views of Andrew Sartori on the place of the history of political economy in a new research agenda for the field of global intellectual history. ${ }^{23}$ Sartori called for a materialistic turn in intellectual

critical point of view: F. Boldizzoni, The poverty of Clio. Resurrecting economic history (Princeton 2010). 20 J. Levy, 'Capital as process and the history of capitalism', Business History Review 91:3 (2017) 483510 .

21 E. Cook, The pricing of progress. Economic indicators and the capitalization of American life. (Cambridge 2017). Indeed, Cook's theorization of investmentality and capitalization are invaluable for the further study of the global circulation of ideas of political economy.

22 For the historiographical connections between political economy and empire see: P. van der Geest, 'Political economy in empire / Empire in political economy. New insights from intellectual and imperial history', tseg/Low Countries Journal of Social and Economic History 15:4 (2018) 99-116. For the most recent development in the history of political economy, R. Fredona and S.A. Reinert, New perspectives on the history of political economy (Basingstoke 2018).

23 A. Sartori, 'Global intellectual history and the history of political economy', in: S. Moyn and A. Sar- 
history, leading to an approach to political economy as the analysis of practical consequences of ideas on individual subjectivities, instead of a description of their mere intellectual genealogy. The particular status of the abstractions (ideas) of political economy - vis a vis other abstractions such as the cultural ones - lies in their performativity. The abstract social world created by such abstractions - a market-place inhabited by rational actors - has an influential role in shaping individual subjectivities. Therefore, according to Sartori, 'political economy must be understood as a discourse whose intellectual history has been constitutively bound to the emergence of 'the social' as a realm of objective interdependence grounded in the mediating role of labour.'.

This seems exactly the political economy and spreading capitalism 'in action' of the imperial interactions in the nineteenth century Indian Ocean studied by the authors under review here. Doing so, these studies provide some important clues for the future avenues of the study of political economy and the history of capitalism. If we take capitalism as a historical system, ${ }^{25}$ a central point of its study is to trace the moment(s) in which capitalist logics started to be the main law of motion of a society. Studying this in relation to the notion of the performative or material character of political economy is crucial to explore the circulation, acceptance and contestation of the rise of capitalism on a global scale, as well as its transformative power over old ideas and social practices. This would call for a research agenda that studies the transition to capitalism from the point of view of the circulation of liberal ideas of political economy by looking at 1 ) how and when markets and market principles became a compulsion instead of an opportunity for economic actor; 2) how the mechanisms that backed the push to participate in and through the realm of the market were designed and how they operated; and 3) how the state or colonial power - and its legislation - played a key role in promoting these economic changes in the

tori (eds.), Global intellectual history (New York 2013) 110-133. The edited volume as such has been critiqued for their restricted selection of themes and the 'parochial profile' of contributors: S. Subrahmanyam, 'Global intellectual history beyond Hegel and Marx', History and Theory 54:1 (2015) 126-137. 24 Sartori, 'Global intellectual history', 114.

25 E. Meiksins Wood, The origin of capitalism. A longer view (London/New York 2017); J. Banaji, 'Globalising the history of capital. Ways forward', Historical Materialism 26:3 (2018) 143-166. In this article, Banaji criticises Meiksins Wood because she believes that pre-modern commerce was not working according to a capitalist logic. However, she never denies that profit-maximization and technical innovation were not features of pre-modern trade. Her point is that the profits came mostly from trading commodities between fragmented markets, and therefore the inner logic was 'the exchange of reciprocal requirements' (see, p. 76). 
mode of production, as well as the multiple responses of local actors to governmental efforts, and their differential ability to influence the political decisions.

Regarding the last point, it is important to highlight the role played by what all three authors call 'colonial anxiety'. The need to regulate the economic world with familiar rules stemmed from the inability of British merchants to understand the mechanisms of an alien economy, and from the fact that flexible local practices were not fitted to the predictability given by statistics in a capitalist market. Therefore, merchants 'turned to the colonial state'. ${ }^{26}$ The anxiety affected also colonial officials, aware of the abilities of local actors to escape their regulations. The driving force behind the institutionalization of a capitalist market in the Indian Ocean was the combined anxiety of merchants looking for profits and colonial officials looking for power.

\section{Conclusion}

The discussion has highlighted new and exciting opportunities in global intellectual history of political economy. The three books under review, through a careful scrutiny of primary sources, have shown to what extent political economic ideas were part of the process of social change related to the expansion of colonial governmental power and the inclusion of the Indian Ocean world in a growing and interdependent world market. Those concepts were deployed by state officials (as suggested by Sartori) and appropriated in different ways by local actors. A perspective centered on the implications of the circulation of particular political economic ideas implied the reconsideration of the performative role of law in the transition to capitalism in the Indian Ocean, allowing relating global connections to local change. ${ }^{27}$

At the same time, intellectual history can benefit from a materialist turn - the attention to the performativity of ideas - to surpass a contextualist approach or the study of the intellectual genealogy of influential currents of thought. The three studies under review support the importance of this shift. In addition, the case of the Indian Ocean has demonstrated the necessity of a close reading of primary sources in order to explore the agency of historical actors. While this can be a burden for 
global historians that are not familiar with non-European languages, it can also be an opportunity for an alternative use of European sources. For instance, a reading against the grain of bureaucratic sources can shed new light on the process of nation-state building and consequent social change. In which way political economy was used as a dispositive of governance in different European states? How did the creation of a capitalist market through a new legal apparatus influence previous social formations in various European regions? How did the different transitions to capitalism affect the development of individual subjectivities in national contexts? In answering those questions, Europe might turn from a subject to an object of study of global history, thanks to the lessons learned from the multiple and multifaceted stories outside its borders.

\section{About the author}

Mattia Steardo (1994) recently obtained his research master in Colonial and Global History from Leiden University. He is currently doing research on the circulation of ideas of political economy in nineteenth-century Sicily, following his interests in intellectual history of political economy. and global economic history.

E-mail:m.steardo@gmail.com 


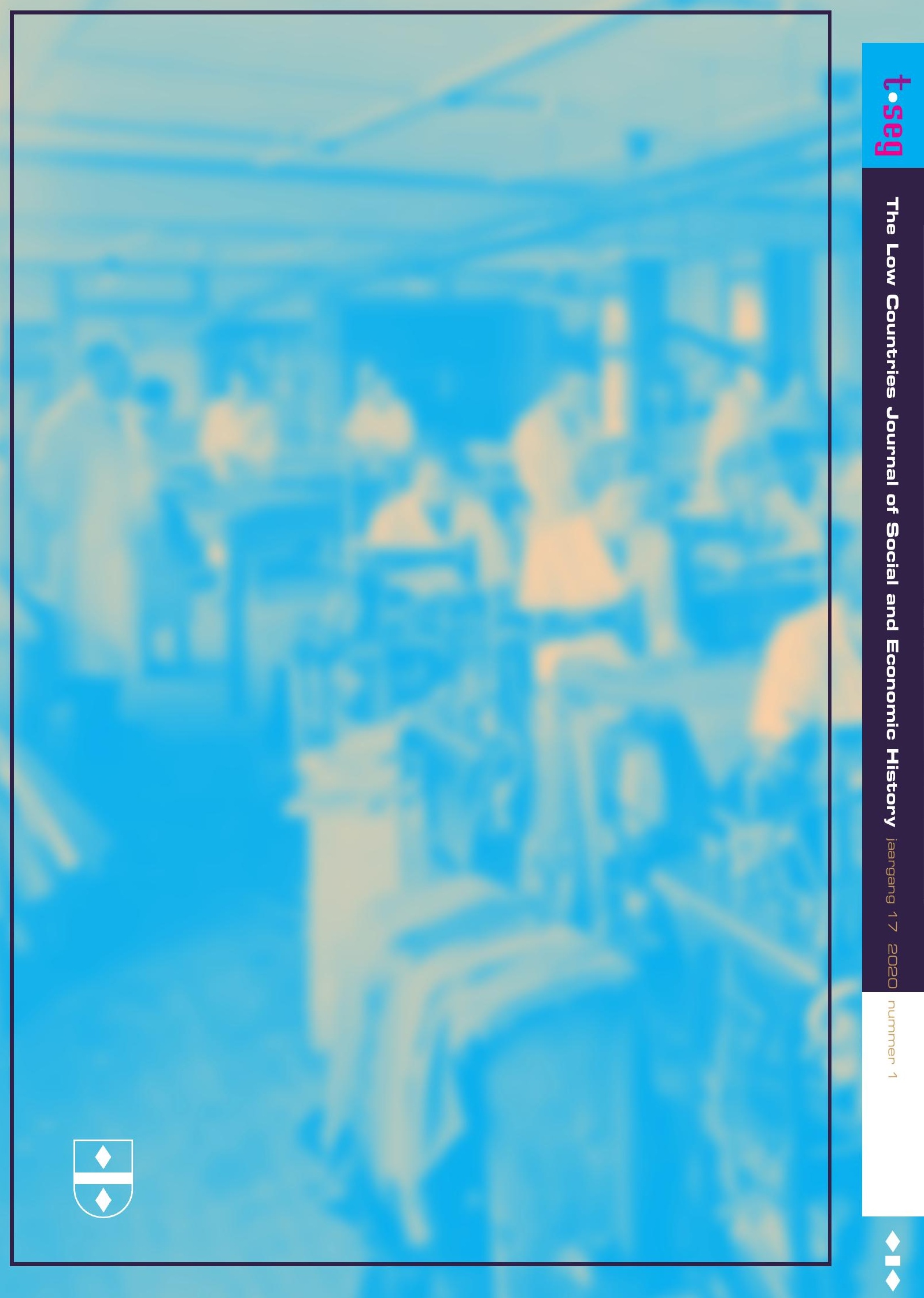

